\title{
ABUSO DE AUTORIDADE E USO LÍCITO DE ARMAS DE FOGO À LUZ DO PRINCÍPIO DA PROIBIÇÃO DO EXCESSO-CONTRIBUIÇÕES DA HERMENÊUTICA CONSTITUCIONAL
}

\author{
Fernando Antonio da Silva Alves ${ }^{1}$
}

\begin{abstract}
RESUMO
Este artigo pretende fazer uma exposição sobre o tema do abuso de autoridade, enfocando seu conceito e circunstâncias em que ocorre, correlacionando o exercício da função estatal com as diretrizes político-constitucionais para a regulação da violência policial, de acordo com os princípios constitucionais.
\end{abstract}

Palavras-chave: Abuso de autoridade. Uso de armas de fogo pelo agente público. Violência policial. Princípios constitucionais.

\section{ABSTRACT}

This article intends to do an explanation about abusive authority acts cases, abording their concept and circunstances that appears, correlating the state function exercize with political and constitutional demands to discipline the police violence, according to constitutional principles.

Keywords: Abusive authority acts. Public agent's weapons use. Police violence. Constitutional principles.

\section{INTRODUÇÃO}

O novo constitucionalismo depara-se com os desafios da modernidade tardia. A linha neoliberal adotada pelo projeto hegemônico da globalização tende a pregar supostos valores de uma pós-modernidade, como se o Estado Moderno e suas instituições tivessem acabado². No simulacro de modernidade vivido pelo Brasil as promessas da modernidade ainda não se realizaram. Enquanto que o discurso neoliberal indica as vantagens da desregulamentação,

\footnotetext{
${ }^{1}$ Mestrado em Ciências Sociais pela Pontifícia Universidade Católica de São Paulo, Brasil(2005) Recentemente foi aprovado em concurso público para a cátedra de Professor Assistente de Direito Penal na Universidade Federal do Estado do Rio de JaneiroUNIRIO. Homepage: www.rn.gov.br

2 STRECK, Lenio Luiz. Hermenêutica jurídica em crise. Porto Alegre: Livraria do Advogado, 2005. Pág. 23 25.
} 
RFD- Revista da Faculdade de Direito da UERJ, v.1, n. 19, jun./dez 2011.

no Brasil nem sequer restou concluída a passagem de um típico Estado Liberal para um

Estado Providência. As políticas de welfare state desenvolvidas timidamente nos últimos anos, ainda não conseguiram deixar um legado de inclusão social, como meio para o exercício de uma cidadania plena e autêntico cumprimento dos direitos fundamentais consagrados nas normas constitucionais.

Vive-se, portanto, uma realidade local que espelha as contradições da realidade global. Assim como em diversos campos do mundo, aqui, no vasto território nacional, encontram-se as classes distribuídas entre uma maioria de excluídos e uma minoria de incluídos no processo econômico de produção e acúmulo de riquezas. Mantém-se a dicotômica e por vezes conflituosa relação entre sociedade civil e sociedade política, onde os agentes do Estado cotidianamente são convidados a estabelecer a repressão dos mais pobres. Episódios lapidares como o caso da Favela Naval, ocorrido na década de noventa do século passado, em Diadema, São Paulo, onde policiais militares desrespeitaram, torturaram, extorquiram e até mataram populares em blitz ilegais, revela o fosso social que separa os homens de farda dos descamisados.

Além disso, o simbolismo das elites ainda é pautado por signos de poder econômico. A ideologia do bacharelismo presente no país desde o surgimento das primeiras cátedras jurídicas no século XIX, somada ao símbolo da autoridade, difundido entre os altos estamentos do poder público nacional, criou um universo de homens letrados, mas também sequiosos de símbolos do poder e ascensão social, compondo um bacharelismo reprodutor dos sentimentos do Estado ${ }^{3}$. A cultura do "você sabe com que está falando", curiosamente detectada no estudo realizado por Roberto da Matta, acaba por revelar a lógica autoritária dos agentes de estado, reforçada pelo monopólio do uso da força, fomentadora de abusos e de práticas irregulares no exercício da função estatal, das mais questionáveis ${ }^{4}$. Torna-se difícil, ante o cotidiano da violência estatal, definir os graus de legitimidade no exercício da força, como forma de defesa da cidadania e das garantias fundamentais, diante de condutas proibidas ou reprovadas pelo ordenamento, separando a ação legítima das ações ilegais e

\footnotetext{
${ }^{3}$ WOLKMER, Antônio Carlos. História do direito no Brasil. Rio de Janeiro: Forense, 2002. Pág.98

4 DA MATTA, Roberto. Carnavais, malandros e heróis - para uma sociologia do dilema brasileiro. Rio de Janeiro: Rocco, 1997. Pág. 187.
} 
RFD- Revista da Faculdade de Direito da UERJ, v.1, n. 19, jun./dez 2011.

frontalmente abusivas por parte dos agentes estatais, que culminam com uma afronta ao próprio Estado de Direito.

O gigantismo do Estado impõe-se como um Leviatã pós-moderno, com suas políticas repressivas de segurança apesar das contradições de um sistema global que prega democracia e respeito aos direitos do homem, face o caráter tardio da modernidade em solo tropical. Ao mesmo tempo em que o Estado aparece em toda sua pujança ao se tratar de inibir ou limitar direitos de cidadania, ele desaparece na pregação neoliberal, ante os imperativos do mercado de desregulamentação econômica. Como saída ao dilema do antagonismo entre o autoritarismo do aparato estatal e a flexibilização econômica do mercado recorre-se ao texto constitucional. É na Constituição que se encontram os suportes hermenêuticos capazes de deslindar o encilhamento normativo sobre os limites da ação estatal, disciplinando a conduta dos agentes públicos e afirmando uma nova esfera de intervenção do Estado, freando ações abusivas. Somente na seara dos direitos fundamentais, e, dentre eles, os direitos relativos à ação cidadã de combate às práticas estatais abusivas, é que poderá a sociedade conviver com seus representantes armados, centuriões exercendo no âmbito das urbes seu munus administrativo, sem violar ou afrontar direitos mínimos, peculiares à própria condução humana e social. É o que será visto a partir de agora ao se traçar a definição jurídica e a delimitação constitucional do abuso de autoridade, relacionando-o aos casos que envolvem o emprego de armas de fogo. Viveu-se por tempo demais sob o espectro de regimes totalitários onde o emprego da arma era símbolo de opressão ou de resistência. Agora, em plena era da afirmação de novas juridicidades, afeitas a um Estado Democrático de Direito, urge apelar para novas concepções sobre o monopólio da força legítima empregado pelo Estado. Não há de se falar de emprego da força estatal, sem antes tratar dos correlatos direitos fundamentais relacionados a este fato.

\section{O DIREITO DE REPRESENTAÇÃO NO ROL DOS DIREITOS FUNDAMENTAIS- INSTRUMENTO CONTRA O ABUSO DE AUTORIDADE}

\section{O que é o direito de representação?}


O direito de representação está previsto no artigo 1.0 da Lei 4.898/65, e consiste num

dos direitos fundamentais assegurados constitucionalmente, mantido implicitamente no direito de petição. Houve a recepção constitucional do citado diploma legal, incluído o direito previsto no artigo 1.o., entre os direitos fundamentais individuais, no seu artigo 5.o., inciso XXXIV, letra "a", da Constituição Federal"

Segundo Bilac Pinto, autor do projeto de lei que veio a se converter na lei 4.898 , ainda no ano de 1956, institui-se entre os direitos e garantias individuais o direito do cidadão representar por abusos cometidos pelas autoridades investidas do papel de velar pelas leis. É um direito conferido a quem quer seja, representando contra os abusos de autoridade e promovendo a responsabilidade dela por tais abusos, conforme ainda alude o art. 121, parágrafo 47 da CF.

O direito de representação é exercido por meio de petição. A vítima, seu representante legal ou procurador, dirige-se por petição à autoridade superior, militar ou civil, para aplicação de sanções administrativas, ou então representa ao Ministério Público, para apuração dos fatos na seara penal. No tocante a vitima, a vítima de um abuso de autoridade pode ser qualquer pessoa, adulto, criança ou adolescente, capaz ou incapaz, brasileiro ou estrangeiro, bem como pessoas jurídicas. Para alguns autores, como Damásio de Jesus, no crime de abuso de autoridade haveria uma dupla subjetividade passiva, pois o cidadão seria o sujeito passivo imediato, enquanto que o Estado seria o sujeito passivo mediato de uma conduta ilícita, adotada abusivamente por um de seus agentes ${ }^{6}$.

No que versa sobre a competência, para o caso de julgamento dos crimes de abuso de autoridade, entende-se por força de regramento constitucional, que estabeleceu os limites de competência dos poderes do Estado e dos órgãos jurisdicionais, as seguintes alternativas: a) quando o sujeito ativo é servidor federal da administração direta ou indireta, a competência será da Justiça Federal; b) quando a vítima estiver sob proteção federal: também se fïrma a competência da Justiça Federal (Ex: caso dos indígenas protegidos pela FUNAI). c) quando o sujeito ativo for policial militar: entende-se que a justiça competente é a justiça estadual, e não a justiça militar, visto que o crime descrito não é crime militar. d) quando o crime de abuso é praticado em concurso com o homicídio: a competência é do Tribunal do Júri.; e)

\footnotetext{
${ }^{5}$ FREITAS, Gilberto Passos. FREITAS, Vladimir de Passos. Abuso de autoridade. São Paulo: Revista dos Tribunais, 2001. Pág. 22-27.

${ }^{6}$ Idem. Pág. 22.
} 
RFD- Revista da Faculdade de Direito da UERJ, v.1, n. 19, jun./dez 2011.

quando o crime é praticado por Prefeito Municipal: a competência é do Tribunal de Justiça (CF, art. 29, VIII), ou do TRF no caso da infração ter sido praticada em detrimento de bens ou serviços da união ou entidades autárquicas (CF, art. 109, IV).f) quando o crime é praticado por Governador, Desembargador, membro do MP que funcione perante os tribunais, a competência será do STJ (CF, art. 105, I);g) quando o crime é praticado por presidente da república, vice-presidente, ministros de Estado, membros do congresso nacional, e procurador geral da república, os crimes são de competência do STF (CF, art. 102, I, b e c).

E o que ocorre no caso de ausência de representação? Ficaria prejudicado o exercício da cidadania contra o abuso de poder caso a vítima não represente contra o autor do abuso? Sobre isso, pode-se dizer que a representação constitui-se de uma mera delatio criminis postulatória, ou seja, é notícia-crime provocada. Como o crime de abuso de autoridade é de ação pública incondicionada, nada impede que, ausente a representação, o fato seja apurado. Portanto, a falta de representação não impede a instauração de ação penal por crime de abuso de autoridade. $\mathrm{O}$ crime pode ser investigado em inquérito policial ou mediante o fornecimento dos documentos necessários à denúncia, como postula o artigo 40 do $\mathrm{CPP}^{7}$.

\section{DO ABUSO DE AUTORIDADE}

\section{Conceito e circunstâncias em que ocorre}

Segundo o art. 3.o. da Lei 4.898/65, abuso de autoridade é todo ato praticado por quem é investido de um poder legal estatal, atentatório contra direitos e garantias individuais sacramentados constitucionalmente e consagrados internacionalmente nas Declarações de Direitos do Homem, tais como: a) liberdade de locomoção; b) inviolabilidade do domicílio; c) sigilo da correspondência; d) liberdade de consciência e crença; e) livre exercício de culto religioso; f) liberdade de associação; g) direitos e garantias legais assegurados ao exercício do voto; h) direito de reunião; i) incolumidade física do indivíduo; j) direitos e garantias legais assegurados ao exercício profissional.

Sobre a definição de abuso de poder e abuso de autoridade. Na esfera do Direito Administrativo, define-se este último como o abuso como a conduta do agente público. Já se encontra disciplinado quanto ao regramento do hábeas corpus, estabelecido no art. 5.o.,

\footnotetext{
${ }^{7}$ Idem. Pág. 26.
} 
inciso LXVIII da Constituição da República, quando é cabível em casos de alguém se sentir ameaçado de sofrer violação ou coação em sua liberdade de locomoção, por ilegalidade ou abuso de poder ${ }^{8}$. Veja-se que é justamente no tolhimento da liberdade de locomoção que se iniciam os atos abusivos delineados no artigo 3.o., do citado diploma legal, além do artigo 4.o., que disciplina os demais casos em que se constitui o abuso de autoridade, como submeter a constrangimento pessoa sob a guarda ou custódia do agente público ou deixar de comunicar imediatamente ao juiz competente a prisão desta pessoa.

No tocante aos casos de abuso de autoridade cometidos por atos de violência policial, associam-se muitas vezes a esses casos os atos atentatórios à incolumidade física. Sobre a relação entre incolumidade física e violência estatal, entende-se inicialmente na leitura da Lei 4.898, que a incolumidade física descrita no artigo 3.o., pressupõe para o seu conceito a ausência de violência física contra a pessoa. Essa violência, que comprometeria à incolumidade física, envolveria desde o homicídio até as vias de fato.

Não obstante, parte da jurisprudência, considerar apenas a violência física no tocante à incolumidade física, no crime de abuso de autoridade, parte da doutrina penalista (notadamente a italiana), considera também a existência de violência imprópria, ou seja, aquela produzida por outro meio que não o físico. Assim, segundo Antolisei, com exclusão da ameaça, temos como meios de violência não físicos: a narcotização, o emprego de gases, disparo de armas de fogo, omissão ou obrigar a vítima a adotar determinado comportamento 9 . Vale salientar os casos em que a vítima da violência for criança ou adolescente, quando se aplica então o diploma legal específico, com suas normas protetoras voltadas a destinatários específicos, dentre os absolutamente ou relativamente incapazes, fazendo valer o artigo 233 da Lei 8.069/90.

Agora qual distinção poderia ser feita entre casos genuínos de abuso de autoridade e casos onde prevalecem suas excludentes de criminalidade? Seriam, portanto, aqueles casos em que, uma vez praticado o abuso, este deixa de ser considerado criminoso, por força de disposição legal. O artigo 292 do CPP preceitua que se houver resistência à prisão em flagrante ou determinada pela autoridade competente, mesmo por parte de terceiros, o

\footnotetext{
${ }^{8}$ BANDEIRA DE MELO, Celso Antônio. Curso de direito administrativo. São Paulo: Malheiros Editores, 2000. Pág. 214.

${ }^{9}$ Antolisei apud Sanches Garcia. SANCHES GARCIA, Maria Isabel. Ejercicio legítimo del cargo y uso de armas por la autoridad. Barcelona: Jose Maria Bosch Editor, 1995. Pág. 24.
} 
RFD- Revista da Faculdade de Direito da UERJ, v.1, n. 19, jun./dez 2011.

executor da medida coercitiva ou seus auxiliares poderão se utilizar dos meios necessários para defender-se ou vencer a resistência, lavrando-se auto, subscrito por duas testemunhas.

O estrito cumprimento do dever legal está dentro daquilo que Max Weber definiu como monopólio legítimo da força, que caracteriza o Estado, investido de um poder legalracional, que se apóia na crença de que a legitimidade da ação do Estado viria da legalidade de um ordenamento estatuído, onde, por sua vez, seus agentes estariam investidos legitimamente de poder $^{10}$. Conforme, portanto, o entendimento weberiano, a violência estatal, dentro dos parâmetros legais, seria então a única forma de violência licitamente aceita, configurando o abuso como um desvio dessa legalidade e uma afronta ao Estado de Direito ordenadamente constituído pela sociedade moderna.

Para Macedo Soares, reforçando a concepção weberiana, se o emprego da força é justificado no caso de recusa do infrator em obedecer a ordem legal, sem o seu emprego, a lei e a justiça ficariam desarmadas. Waldemar César da Silveira pensa da mesma forma, afirmando que a violência legítima estatal manifesta-se em que coage as pessoas à execução das leis ou faz com que estas obedeçam às imposições da Justiça. Sem o emprego da força, a lei e a justiça se desarmariam ${ }^{11}$.

Veja-se, quanto ao assunto, o entendimento da jurisprudência:

"Se o preso, ao reagir à sua autuação em flagrante, deu lugar a uma necessária ação da polícia, no sentido de levar a efeito o ato, não se configura o delito de abuso de autoridade". (RT 447/486- TAPR RT 601/348- TACRIM)

E nos casos de abuso de autoridade onde existe lesão corporal? Qual seria o entendimento? A esse respeito, ainda no aspecto da incolumidade física do indivíduo no crime de abuso de autoridade, se o abuso é praticado, concomitantemente com a produção de lesão na vítima, a doutrina dominante entende que houve concurso material, ou seja, a prática de lesão corporal não é absorvida pelo abuso de autoridade ${ }^{12}$.

Aplica-se, portanto, a cumulação de penas. $\mathrm{O}$ crime de abuso foi tipificado para resguardar os direitos constitucionais de cidadania, contra desmandos da autoridade e seus agentes, enquanto que a lesão corporal foi regrada entre as infrações comuns, previstos no Código Penal (legislação infraconstitucional).

\footnotetext{
${ }^{10}$ TREVES, Renato. Sociologia do direito. Tradução Marcelo Branchini. Barueri: Manole, 2004. Pág. 167.

${ }^{11}$ FREITAS, Gilberto Passos. Ob. Cit. Pág.57.

12 Idem. Pág.58.
} 
Mesmo raciocínio deve ser adotado nos casos de abuso de autoridade e crime de

tortura. Se o abuso é cometido pela autoridade com o intuito de obter informação, declaração ou confissão, ou ainda para provocar uma ação ou omissão criminosa, atingindo a incolumidade física do indivíduo, trata-se de crime de tortura, previsto na Lei 9. 455/97, na forma de seu artigo 1.o., inciso I, $a$ e $b$. Também nesse caso, pode haver concurso material entre crime de abuso de autoridade e tortura.

\section{VIOLÊNCIA POLICIAL, EMPREGO DA FORÇA E USO LÍCITO DE ARMAS DE FOGO}

\section{Critério de legitimidade do uso da força}

Do ponto de vista político e sociológico, os conceitos de força e violência não são diferenciados apenas com base na legalidade, mas também na legitimidade da força física ${ }^{13}$. Os casos de violência policial não são apenas os que envolvem o uso ilegal da força pelo agente munido da autoridade estatal (brigas na vizinhança ou conflitos domésticos), mas também no uso ilegítimo da força física. Um exemplo que pode ser traçado encontra-se nas ações policiais de preservação da segurança publica, quando ocorre a troca de tiros em via pública entre policiais e bandidos perseguidos, provocando a morte de várias pessoas inocentes, entre o tiroteio.

É comum no cotidiano da violência estatal o uso ilegítimo da força mobilizar a opinião pública. Pautando-se pelo critério da legitimidade e não apenas da legalidade, percebe-se que do ponto de vista da opinião pública, não apenas os atos de violência ilegais e abusivos são objeto de crítica, mas também aqueles atos considerados irregulares, anormais, escandalosos ou chocantes. Um exemplo disso são atos praticados pela polícia em desacordo com padrões de comportamento estabelecidos pela imprensa ou opinião publica,

\footnotetext{
${ }^{13}$ MESQUITA, Paulo, in Violência policial no Brasil: abordagens teóricas e práticas de controle. PANDOLFI, e outros (organizadores). Cidadania, justiça e violência. São Paulo: FGV, 1999. Pág. 133.
} 
RFD- Revista da Faculdade de Direito da UERJ, v.1, n. 19, jun./dez 2011.

como por exemplo: a organização de barreiras com armamento pesado para abordagem, revista e interrogatório de pessoas que são paradas nesses lugares ${ }^{14}$.

\section{Concepção profissional de violência policial}

Segundo a concepção defendida por Carl Klockars, a violência policial não se resumiria apenas a um ato abusivo ilegal, ilegítimo ou irregular de exercício da força física, mas sim pelo uso maior de uma força física que um policial altamente competente necessitaria para utilizar em uma determinada situação. A concepção profissional de violência policial, diferentemente das visões normalmente apresentadas de violência baseada no uso ilegal ou ilegítimo da força, está vinculada à idéia de experiência profissional da autoridade estatal. Esta concepção indica que abusos de autoridade ocorridos pela prática da violência policial consistem em comportamentos antiprofissionais, não- profissionais ou pouco profissionais ${ }^{15}$.

Afirmar que uma dada conduta de um agente estatal, no exercício da função é antiprofissional, implica em dizer que o abuso de autoridade pela violência policial, para esta concepção, seria mais oriundo da falta de profissionalização da polícia e da melhoria do aperfeiçoamento profissional dos agentes estatais, do que uma dolosa conduta individual do agente de afronta à legalidade, carente de legitimidade. Ora, antes da punição do agente estatal, numa ótica preventiva de intervenção estatal enquanto defesa social, deveria o Estado estabelecer uma relação de cooperação entre os agentes estatais e os cidadãos, e não de conflito. Isto envolveria a compreensão e o controle da violência policial, através da formação continuada e da especialização. Não basta que o agente estatal munido de autoridade saiba dos limites legais de seus atos, mas também dos aspectos ligados à legitimidade, regularidade e profissionalismo no exercício de suas funções. Tal questão remete-se diretamente à discussão sobre o emprego de armas de fogo, a preparação, habilidade e regras para manejo.

Mas, conforme esse entendimento, o que diz o direito comparado sobre o emprego legítimo da força, justamente o inverso da violência ilegítima?

\section{O direito comparado e o emprego legítimo da força}

\footnotetext{
${ }^{14}$ Idem. Pág. 134.

${ }^{15}$ Idem. Pág. 135.
} 
1) No Direito Francês: O artigo 122.4, parágrafo primeiro do Código Penal Francês estabelece a justificação jurídico-penal das ações típicas praticadas por funcionário público no exercício de suas funções, afirmando que "não é punível quem executa um ato prescrito e autorizado por disposições legislativas ou regulamentares”. O novo Código Penal na França foi promulgado em 22.7.1992 e sua entrada em vigor deu-se em 1.3.1994. O artigo 122.4 veio substituir o antigo artigo 327, situado na Parte Especial, que excluía a responsabilidade penal das condutas de homicídio ou lesões corporais quando estivessem ordenadas por lei ou por ordem de autoridade legítima ${ }^{16}$.

Havia uma polêmica na doutrina francesa com a redação antiga do artigo 327 , se havia a exigência de duas condições para declarar conforme o direito uma conduta típica (antijuridicidade): a existência de prescrição legal e a ordem de autoridade legítima. Admitia-se que era suficiente a emanação de uma ordem legal, pois se alegava que o agente público não poderia ficar esperando a ordem de uma autoridade superior, sob pena de descumprir a lei, no momento em quer obrigado a cumpri-la. A polêmica foi resolvida com a redação do novo artigo 122.4, referindo-se unicamente a ordem ou autorização de uma lei ou regulamento.No tocante ao abuso de autoridade, é o artigo 432.4 do Código Francês que sanciona penalmente a conduta do funcionário que ordena ou executa arbitrariamente um ato atentatório contra a liberdade individual.

2) No Direito Italiano: O artigo 51 do Código Penal Italiano, seguido desde 1930, estabelece que "o exercício de um direito e o cumprimento de um dever imposto por uma norma jurídica, ou por ordem legítima excluem a punibilidade".

3) No Direito alemão: Não há norma específica no Código Penal Alemão, de 1987, com a previsão expressa da causa de justificação da violência do agente público, no exercício de um direito ou profissão. A literatura penal alemã prefere discutir as causas de justificação no exercício de cargo público no âmbito da doutrina, aludindo ao princípio da unidade do ordenamento jurídico e o caráter geral do juízo de antijuridicidade.

Segundo Jescheck: "as causas de justificação devem deduzir-se do ordenamento jurídico em seu conjunto”. Devem-se verificar em diferentes textos do Direito Público (especialmente do Direito Processual e do Direito Administrativo), quais as normas que

\footnotetext{
${ }^{16}$ SANCHEZ GARCIA, Izabel. Ob.cit.Pág.41.
} 
contêm mandados e autorizações relativas à intervenção coativa do Estado, que podem ser lesivas à liberdade dos cidadãos, pois do ponto de vista jurídico-penal, teriam estas normas, segundo Amelung, a eficácia de causas de justificação ${ }^{17}$.

Partindo de diferentes preceitos jurídicos a doutrina alemã estabeleceu o conceito geral de "exercício do cargo público", incluído na parte geral dentro do rol das causas de excludente de antijuridicidade. Nesse sentido Mezger considera as "ações realizadas em virtude de deveres especiais", Maurach se refere a "forçosa execução estatal", situação própria "do encarregado do poder de Estado que leva a cabo em seu âmbito de competência ações tipicamente ordenadas pela lei”.

4) No Direito suíço: O ordenamento penal suíço é próximo do espanhol quando trata no artigo 32 do Código Penal vigente desde 1937 (com modificações posteriores), sobre a exclusão da antijuridicidade fundada na existência de um dever de cargo profissional, assim como por um mandato ou autorização legal. Nos artigos 33 e 34 o exercício do cargo está agrupado junto à legítima defesa e o estado de necessidade, nominados sob a rubrica de "atos lícitos".

Entretanto, segundo Noll, este preceito pode ser qualificado como "norma penal em branco", pois deve se fundamentar em leis e princípios jurídicos (incluindo-se a jurisprudência). As intervenções estatais violentas nos direitos constitucionalmente reconhecidos do cidadão devem apoiar-se em todo caso na lei no sentido formal, geralmente numa norma de âmbito federal ou regional, de Direito Processual Civil, Penal ou Direito Administrativo ${ }^{18}$.

5) No Direito do Reino Unido e dos Estados Unidos: O sistema penal anglo-saxão apresenta grandes diferenças em relação ao sistema continental europeu. Boa parte do ordenamento jurídico ainda está sujeito ao Common Law, de origem consuetudinária e formato jurisprudencial, fundado nos case law e o Statute Law, que é o direito regulado pelo Parlamento.

A definição de delito integra dois elementos actus reus e mens rea. Utiliza-se o princípio geral do direito que estabelece: “actus non facit reum nisi mens sit rea". Actus, de natureza objetiva, diz respeito aos elementos externos do ato. Mens rea é o elemento mental do delito, de natureza subjetiva. Isto implica em dizer que para a responsabilização penal de

\footnotetext{
${ }^{17}$ Idem.Pág.44.

${ }^{18}$ Idem. Pág.46.
} 
RFD- Revista da Faculdade de Direito da UERJ, v.1, n. 19, jun./dez 2011.

uma pessoa, além dela ter feito algo proibido pela lei penal em sua conduta, a conduta deve estar acompanhada de um estado mental pré-determinado. Uma pessoa que houver cometido um ato que corresponde à definição de delito pode não ser responsabilizada pelo ato, se ocorreu uma "defence”. O conceito de "defence" é amplo, podendo envolver todas as causas que fazem desaparecer algum elemento do delito, assim como aquelas legalmente estabelecidas, onde, apesar da presença de todos os elementos do crime, se resguarda o autor da responsabilidade penal.

Dentre as "defences" destacaram-se historicamente as "circumstances de justification of excuse”. Sua definição vem do Common Law a partir da dupla distinção no julgamento dos crimes de homicídio (puníveis e não puníveis). Ex: homicídios que resultaram da execução de uma sentença de morte por um carrasco, a morte provocada no curso de um cerco a um perigoso criminoso, que tenta fugir, seriam escusáveis, ou seja, condutas justificadas. A sentença nesses casos era absolutória, mas se somente o homicídio era escusável, e não conduta distinta, nos outros casos os bens do autor podiam ser confiscados, conformo dispunha o Commom Law. Com a revogação do dispositivo do confisco em 1928, essa classificação perdeu seu sentido tanto nos tribunais, como na literatura jurídica anglo-saxônica.

Recentemente, a doutrina anglo-saxônica reviveu a distinção entre os casos de conduta escusável e inescusável, no exercício da função estatal, mormente a literatura norteamericana. Alguns autores estabelecem as seguintes diferenças: a) as condutas escusáveis podem ser objeto de resistência pela pessoa que a sofre, mas não são justificáveis; b) as condutas escusáveis não podem ser legalmente assistidas por um terceiro, mas são, em troca, justificáveis; c) uma conduta resulta justificada quando o autor desconhecia os fatos que fundamentam a justificação, pois esse conhecimento só é requerido para uma conduta escusada. Para J. Smith, segundo a lei, quando está presente uma escusa, subsiste a responsabilidade civil, o que não ocorre na justificação. Essa diferença advém do fato de que o ato justificado é "querido" pela sociedade, enquanto que o ato escusado é meramente "tolerado".

$\mathrm{Na}$ Inglaterra, País de Gales e Irlanda reconhece-se legalmente o caso específico de exercício do cargo. É excluída a responsabilidade penal pelo uso da força razoável, seguindo as circunstâncias da "prevenção de delitos", para o arresto juridicamente previsto de 
RFD- Revista da Faculdade de Direito da UERJ, v.1, n. 19, jun./dez 2011.

delinquentes, ou de pessoas consideradas "fora da lei" (recorda-se aqui do polêmico caso envolvendo o brasileiro Jean Charles de Meneses, morto pela Scotland Yard, polícia britânica). Nos Estados Unidos, existem várias normas disciplinando o uso da força pela autoridade em numerosos estatutos, de âmbito estadual e federal. Muitos estados seguem o Modelo de Código Penal, que é um código adotado para vários estados, que contém uma rubrica intitulada "Princípios Gerais de Justificação" 19.

\section{Estudo geral das causas de justificação de condutas dos agentes públicos quanto ao uso da força}

No tocante ao cumprimento de um dever, tal causa de justificação encontra-se presente nos artigos 8 e 11 do Código Penal Espanhol. A doutrina jurídica espanhola afirma com unanimidade o que seja a natureza jurídica do dever a que a norma se refere ${ }^{20}$.

O dever jurídico é aquele imposto pela norma jurídica, aquele que permanece ao âmbito do Direito, diferencia-se dos deveres de natureza moral, religiosa, ética e aqueles de conveniência social. Distingue-se também do dever moral de obediência ao direito. "A definição de dever é efetuada na teoria geral do Direito a partir da obra de Kant, na sua definição da "metafísica dos costumes", donde se distingue, com precisão, o mundo da moralidade e o da legalidade.

O dever pode ter sua origem tanto numa norma de direito privado, como numa norma de direito público. Como exemplo dos primeiros pode-se tratar da doutrina referente ao exercício dos deveres inerentes ao pátrio poder (dever de educação, alimentos, administração de bens etc). Quanto aos deveres fixados nas normas de direito público pode ter como destinatário um particular ou funcionário público.

Dentre os deveres fixados pelas normas de direito público ao funcionário estatal, cita a lei o dever do agente público de impedir o cometimento de determinados delitos e levá-los ao conhecimento da autoridade. O cumprimento de um dever dá base à justificação daquelas situações em que o cumprimento do dever público é derivado do âmbito de competência específica, atribuído em virtude de um cargo que se desempenha.

\footnotetext{
${ }^{19}$ Idem.Pág.46-49.

${ }^{20}$ Idem. Pág.51-86
} 
RFD- Revista da Faculdade de Direito da UERJ, v.1, n. 19, jun./dez 2011.

Segundo a legisłação e a doutrina penal nacional, entende-se em cumprimento do

dever o agente que se encontra inserido no caso previsto no inciso III do artigo 23 do Código Penal Brasileiro. Tal redação foi dada com a reforma introduzida em 1984 e o advento da Lei n.o. 7.209, de 11 de julho, que estabeleceu sua redação, vinculando o dispositivo ao disposto nos artigos 386, inciso V e 411 do Código de Processo Penal, sendo motivo para absolvição do réu.

E o que dizer sobre o exercício de um direito? O exercício legítimo de um direito exime de responsabilidade criminal, segundo a doutrina e a lei penal. Envolve a concepção de direito subjetivo tanto em sentido amplo quanto em sentido estrito, dentro do campo do interesse legítimo. É assim que estatui a parte final do inciso III do artigo 23 do Código Penal Brasileiro, salientando-se que o agente responde pelo excesso doloso ou culposo ${ }^{21}$. Dizer que houve excesso no exercício de um direito significa dizer que, assim que cessa o fato que ensejou o exercício do direito, o agente continua atuando, seja dolosamente, seja por motivo vencível, quando no caso do agente policial que faz uso de arma de fogo em serviço, como exercício regular de um direito que a ordem jurídica lhe confere pelo porte legal, mas extrapola a limitação do direito subjetivo que lhe foi conferido, abusando deste; ao efetuar, por exemplo, disparos sucessivos em um potencial agressor, já desarmado ou que faria presumir ao agente não mais oferecer perigo.

O conceito de direito num sentido amplo remonta à doutrina de Santi Romano, que compreende o conceito de direito subjetivo, dentro das definiç̧ões de faculdade, poder, e ação. No âmbito do direito público, conceber o direito como um poder jurídico, implica no uso administrativo de poderes de natureza pública. Assim a atuação do poder estatal, submetendo o cidadão face à violação de normas jurídicas constitui-se num direito a que se arvora o Estado, como no exercício do seu Ius puniendi (direito de punir). O exercício de poderes administrativos identifica-se com o que Santi Romano define como "funções públicas”. Quando o poder é exercido não por um interesse próprio e sim por um interesse público, objetivo utiliza-se o termo "função", sendo que este conceito é predominante no Direito Público. A doutrina identifica que o poder-função do Estado tem, portanto, dupla natureza, ao mesmo tempo é direito, e também é dever.

\footnotetext{
${ }^{21}$ ZAFFARONI, Raul Eugenio. PIERANGELLI, José Henrique. Manual de Direito penal brasileiro-parte
} geral. São Paulo: Revista dos Tribunais, 2002. Pág. 595-596. 
RFD- Revista da Faculdade de Direito da UERJ, v.1, n. 19, jun./dez 2011.

Compete agora saber a definição e a diferença entre os conceitos de ofício e cargo. A expressão "cargo" deve aqui ser entendida como exercício de uma função pública. É largamente utilizado o termo pelo direito administrativo. Já a definição de ofício está relacionada com o exercício de direitos e cumprimento de deveres profissionais, que, por vezes, recebem tratamento similar tanto no direito público, quanto no direito privado.

No direito positivo brasileiro, a definição de cargo está prevista tanto no Direito Administrativo quanto no Direito Penal. Consoante o entendimento constitucional ao versar sobre a administração pública, pode-se entender o cargo como uma unidade estatal indivisível, cuja competência é exercida por um dos agentes do Estado ${ }^{22}$. Os cargos, criados por lei, são exercidos por servidores públicos e a definição de servidor encontra previsão legal no âmbito penal através do artigo 327 do Código Penal Brasileiro, para aqueles que percebam ou não remuneração, tanto para os exercem suas funções diretamente para o Estado (administração direta) ou em entidades paraestatais (empresas prestadoras de serviços contratadas ou conveniadas para a execução de típica atividade estatal), conforme a redação dada pela emenda do citado dispositivo, mediante a publicação da Lei n.o. 9.983, de 14 de julho de 2000. Portanto, em quaisquer dessas condições, pode-se tratar de casos de abuso de autoridade, para aqueles indivíduos denominados servidores públicos, no exercício de suas funções.

Quanto às estratégias para o bom desempenho de um ofício, torna-se necessário, no caso dos agentes públicos, que os direitos e deveres profissionais dos agentes sejam estabelecidos e cultivados pelos dirigentes e administradores públicos (principalmente os da organização policial), bem como pelas corregedorias. Os órgãos de fiscalização não devem apenas cuidar da apuração e repressão das faltas disciplinares, mas também serem responsáveis pela conscientização dos direitos e deveres do ofício.

A concepção profissional de violência policial já estudada pode ser empregada quando se enfatiza a importância dos mecanismos de controle interno e informal, ou convencional das polícias. Esse controle é efetuado com medidas de profissionalização, apoiadas em padrões de competência e responsabilidade profissional. O controle é útil na detecção de usos antiprofissionais, não profissionais ou pouco profissionais de força física

\footnotetext{
${ }^{22}$ BANDEIRA DE MELO, CELSO ANTONIO. Ob.Cit.Pág.225.
} 
RFD- Revista da Faculdade de Direito da UERJ, v.1, n. 19, jun./dez 2011.

por policiais ${ }^{23}$. Envolve um tipo de conhecimento e informação controlado pelos policiais e por suas associações profissionais.

Sobre a obediência devida é importante estabelecer que a obediência devida seja causa excludente da responsabilidade penal, como preceitua o artigo 23 do CPB, que preceitua também sobre o exercício regular de direito. Discute-se na doutrina se a excludente alcança unicamente a execução de ordens lícitas, ou se determinadas ordens antijurídicas podem ser suscetíveis do dever de obediência.

Autores como Cuello Calón e Quitano Ripollés, baseados em decisões do Supremo Tribunal Espanhol só reconhecem como causa de justificação a execução de ordens lícitas. Já os autores que defendem a existência de mandados antijurídicos obrigatórios que impõem obediência, apoiam-se nos casos em que funcionários administrativos ou judiciais são punidos se manifestarem recusa em cumprir sentenças, decisões e ordens da autoridade superior, ditadas dentro dos limites de sua competência e revestidas de forma legal, porém carentes de legitimidade. Cita-se nesse sentido o caso da atuação do policial militar em operações policiais temerárias, que podem expor a risco a vida de cidadãos, como a ocupação de morros e favelas. Nesse caso, não obstante a ordem pode ser questionada pela legalidade, o agente público nada pode fazer, senão cumprir a ordem, sob pena de ser castigado.

Igualmente, pode ocorrer segundo outros autores espanhóis como Asua e Cerezo, um erro invencível do funcionário quanto à ilegalidade da ordem emitida e o princípio da não exigibilidade de conduta distinta. Excluem desses casos as ordens lícitas, que ensejam causas de justificação de conduta pelo cumprimento de um dever. Aqui, mais uma vez o papel das associações profissionais ganha destaque na formação do agente público, uma vez que a relação hierárquica pode, por vezes, comprometer o entendimento do servidor quanto à legalidade, legitimidade e regularidade de seu ofício, vindo o mesmo a tecer entendimentos sobre ordens ilegais, considerando-as legais por pura falta de conscientização de seus deveres profissionais. Compete às organizações de representação profissional, integrantes da sociedade civil, distintas das corporações uniformizadas integrantes da administração estatal, a iniciativa de promover reivindicações quanto à devida formação profissional dos agentes públicos, cobrando o aprimoramento ou modificação dos cursos de

\footnotetext{
${ }^{23}$ MESQUITA, Paulo. Ob. Cit. Pág.137.
} 
RFD- Revista da Faculdade de Direito da UERJ, v.1, n. 19, jun./dez 2011.

capacitação, exigindo avaliação continuada e exercendo monitoramento contínuo da formação profissional de seus membros.

Na distinção já vista entre ofício e cargo destaca-se neste último o caráter público, uma vez que cargo somente pode ser exercido por servidor ou agente público, enquanto que um ofício é noção geral, aplicável tanto a servidores quanto a particulares, relacionado com sua formação e cultura profissional. Distingue-se também no cargo peculiaridades quanto ao exercício de um direito, uma vez que o direito aqui terá um caráter de norma especial. Citase, por exemplo, o direito de portar armas, preceituado no Estatuto do Desarmamento a determinadas autoridades e agentes públicos.

Alguns autores negam a substancialidade própria da causa de justificação pelo exercício legítimo do cargo, frente ao cumprimento de um dever. Citam-se, nesse caso, aqueles que questionam o fato de um servidor burlar a entrada, pulando a roleta ou deixando de pagar o ingresso para shows e espetáculos, alegando a justificação de exercer ali um cargo público. Outros já entendem que há autonomia conceitual no exercício legítimo de cargo e ofício, enquanto simbiose de direitos e deveres. Córdoba Roda afirma que nesse caso tanto um dever quanto um direito podem ter sua origem no ofício ou cargo.

No exemplo citado anteriormente, se em razão do cargo, um servidor tem direito ao acesso a determinados lugares, ele também tem deveres em função do cargo, tais como: não portar armas ostensivamente ou guardá-las em compartimento adequado, efetuar prisões em caso de crimes cometidos em flagrante no local, portar-se com urbanidade e apresentar habilidade no manejo de armas.

O exercício de um cargo público está relacionado com uma função pública específica, ou seja, o cargo vincula-se ao exercício de poderes que pertencem ao âmbito de competência atribuído a cada funcionário. Portanto, o porte de armas é inerente das funções policiais, militares e judiciais, relacionadas ao exercício de funções públicas relativas à defesa interna ou externa ou ao exercício da jurisdição, e não das demais funções estatais, como as vinculadas à educação ou a saúde, por exemplo.

\section{ANÁLISE JURÍDICO-CONSTITUCIONAL DA JUSTIFICAÇÃO JURÍDICO- PENAL DO EXERCíCIO DA COAÇÃo ESTATAL (Princípios da legalidade e proporcionalidade)}




\section{Princípio da legalidade}

Em síntese o princípio constitucional da legalidade estabelece a vinculação positiva da Administração à lei. Irá abranger todas as intervenções restritivas de direitos, subsidiado pelo princípio da necessidade e da proporcionalidade, entendido este último como princípio da proibição do excesso ou princípio da proporcionalidade em sentido amplo. O princípio da legalidade serve para que sejam feitas algumas necessárias e por demais importantes observações sobre a conformidade ao direito da intervenção estatal. É basilar para a formação do Estado de Direito.

Por este princípio deve o agente estatal obter, em primeiro lugar, habilitação legal e competência para o emprego de violência na situação concreta, assim como preencher os requisitos que a lei estabelece para cada caso. A legalidade enquanto princípio constitucional é que deve estabelecer os imperativos legais que determinem o uso de armas como lícito e sua conexão com as funções, para os membros das Forças Armadas e da Segurança Pública do Estado. Nesse sentido é que a lei afasta ou não torna aconselhável o uso de armas de fogo com grande potencial danoso ou alguns tipos de armas químicas e elétricas no exercício de funções policiais, subordinando-se estas ao controle militar.

No tocante à idoneidade do meio e necessidade da intervenção (princípio da necessidade) o princípio da necessidade vem ao auxílio da legalidade para "identificar a necessidade de violência concretamente aplicada, com sua adequação ao meio especificamente interposto às peculiaridades do caso específico" ${ }^{24}$. Segundo Maria Isabel Sanchez Garcia, no exame da necessidade, de forma prévia a qualquer outro meio, deve-se verificar a idoneidade da intervenção para o alcance do fim perseguido. Esse exame é de caráter positivo, empírico, objetivo. Basta para a constatação da necessidade um exame objetivo ex ante.

Já o caráter idôneo de um meio é relativo e está relacionado às características pessoais do funcionário de polícia que o utiliza. O diferente grau de manejo ou destreza de uma arma pode determinar o uso idôneo ou inidôneo desta para diferentes sujeitos. Um exemplo disso foi o caso da morte da professora carioca Geísa, na década de 90, refém em um assalto ao ônibus de n.o. 174 no RJ, em precipitada intervenção policial dos integrantes

\footnotetext{
${ }^{24}$ Córdoba Roda apud Sanchez Garcia. SANCHES GARCIA, Izabel. Ob.Cit. Pág. 290.
} 
RFD- Revista da Faculdade de Direito da UERJ, v.1, n. 19, jun./dez 2011.

do BOPE (Batathão de Operações Policiais), após um cerco de horas a um ônibus cujos passageiros foram tomados como reféns pelo assaltante Sandro do Nascimento. O triste saldo dessa operação policial com emprego indevido de armas de grosso calibre, sem contar na imperícia em seu manejo, resultou na morte da refém e do assaltante, morto pelos próprios policiais antes de chegar à delegacia.

Sanches Garcia trata da necessidade da intervenção violenta em abstrato, que implica casos de exigência de ameaça prévia (aviso de disparo ou disparo de aviso).

A verificação da necessidade in abstracto da violência consiste na comprovação da ineficácia de meios não violentos para o cumprimento de uma função pública, em um dado caso. Ante a negativa do sujeito passivo da intervenção a colaborar, quando, p.ex, não se submete voluntariamente à detenção, devem ser empregados meios não violentos como dissuasão ou persuasão, utilizando, em todo caso, a ameaça prévia do emprego da força.

Trata-se da manifestação do princípio da necessidade in abstracto, como a exigência geral do emprego de uma coação previamente amenizada. Esta medida tem grande adequabilidade quanto ao emprego de armas de fogo. Há que se preceder de um aviso de disparo sempre que o aviso e as circunstâncias o permitam. Ex: casos de fuga de um delinquente. $\mathrm{O}$ aviso de disparo pode ser omitido, evidentemente, em casos de legítima defesa própria ou de terceiros ${ }^{25}$.

No caso de necessidade da intervenção violenta em concreto, enquanto que a necessidade do meio concreto utilizado é regida pelo princípio do emprego do meio idôneo, menos lesivo possível, a necessidade aqui se refere não apenas ao meio considerado em si mesmo, mas também ao modo de emprego e a intensidade do mesmo.

Esse princípio implica em dizer, em primeiro lugar, que, se só se dispõe de um meio, este é o necessário. Quando se dispõe de vários meios idôneos, todos eles capazes de alcançar o fim procurado pela intervenção estatal, deve-se eleger sempre o meio menos perigoso ou danoso. Assim, por exemplo, a utilização de força física, gás lacrimogêneo, balas de borracha, deve sempre preceder a meios mais graves, tais como armas de fogo.

\footnotetext{
${ }^{25}$ Idem. Pág. 292.
} 


\section{Princípio da proporcionalidade}

Determinada a necessidade da intervenção violenta, é preciso ainda efetuar exame posterior da relação entre o meio idôneo e necessário e o fim perseguido pela intervenção. Essa correspondência é feita à luz de critérios de índole valorativa, que são estabelecidos pelo princípio da proporcionalidade.

O princípio da proporcionalidade é um princípio de caráter normativo e se constitui como princípio de natureza constitucional derivado do valor da justiça: em seu sentido de igualdade, como justiça relativa ou distributiva (a cada um de acordo com sua necessidade). É princípio extraído da Filosofia do Direito que hoje se encontra presente em todos os ordenamentos jurídicos democráticos, como exigência própria do Estado Democrático de Direito.

Aplica-se o princípio em matéria jurídico-penal, no sentido de regular a atuação coativa dos órgãos de segurança e força pública do Estado, oferecendo diretrizes materiais e concretas, nos ordenamentos jurídicos democráticos, para a orientação e prática da ação estatal policial. O princípio da proporcionalidade constitui-se em princípio regulador dos conflitos de interesse entre Estado e cidadão. Fornece a imagem que o sistema jurídico deve ter de si mesmo, apresentando um indicador significativo da medida em que o Estado de Direito pode ser, em sentido material, uma garantia que se realiza para o indivíduo.

O exame da detenção, conforme o princípio da proporcionalidade deve levar o agente da autoridade estatal há só se valer de uma prática violenta, de acordo com a gravidade do ato delituoso que a motivou. Outros dados relativos à qualidade da vítima, idade do ofensor ou sua periculosidade, devem ser levadas em conta, assim como a presença de terceiros, que podem ter sua integridade física comprometida ou posta em perigo por causa da intervenção estatal (ex: recordando o caso do tiroteio de policiais e bandidos em vida pública).

Atenção especial merece os casos em que tem lugar um controle policial com uso de veículos (viaturas), quando o delinqüente é surpreendido e empreende fuga. O simples fato de um suspeito fugir, proporcionando um motivo racional de suspeita do cometimento de um delito, não permite o emprego de armas de fogo para assegurar a captura. A suspeita que leva ao emprego de armas só é fundada quando, por exemplo, a autoridade, ao executar a 
RFD- Revista da Faculdade de Direito da UERJ, v.1, n. 19, jun./dez 2011.

ordem de prisão, sabe, de antemão, a identidade da pessoa que vai prender; ou ainda quando efetuado o controle policial, constata-se que a pessoa porta armas ou instrumentos bélicos de qualquer natureza.

Importante discussão quanto à aplicação do princípio pode ser retomado quando se estuda a atuação coativa da autoridade pública frente a um coletivo de pessoas em matéria de ordem pública, o que implicaria na utilização de armas de menor potencial ofensivo. A utilização da violência pública frente a um grande número de pessoas deve levar em conta um tratamento diferenciado e acurado do fato. Trata-se dos casos em que os agentes da autoridade pública têm como destinatários certo número de pessoas em que não é possível discernir quais são, apriori, suspeitos de uma ação delitiva dos que não são.

Isso se sucede, por exemplo, quando a polícia é chamada para enfrentar ou conter uma manifestação popular não autorizada que pode desembocar em atos de violência, tais como: saques, pilhagens, depredações, motins, incêndios, e até mortes. $O$ avanço tecnológico tem permitido a utilização de mais numerosas e sofisticadas armas empregadas para multidões, desenvolvidas no decorrer dos anos sessenta e começo dos setenta do século passado, dada a multiplicação dos movimentos de protesto político, dos conflitos sociais com episódios de violência (como greves, protestos estudantis, distúrbios raciais).

Vale salientar que o uso de armas de fogo contra multidões é juridicamente proibido por convenções internacionais (vide o caso do massacre em Eldorado dos Carajás). O Pacto de San José da Costa Rica recrimina posturas atentatórias aos direitos do homem como o emprego de armas à população civil desarmada. Exceto nos casos individuais em que um policial individualizado repele especialmente uma agressão vinda de um ofensor determinado.

\section{DO PRINCÍPIO DA PROIBIÇÃO DO EXCESSO}

Chega-se, finalmente, ao cerne da discussão sobre a legitimação constitucional do emprego da força pelo Estado, assim como ao conhecimento dos filtros inibidores de caráter constitucional da violência estatal a que se transformam os princípios, no momento em que se compara a norma constitucional com a lei ordinária. Como já foi dito a Lei n.o. 4898/65 foi recepcionada pela Constituição de 1988, inserindo no rol dos direitos fundamentais o 
RFD- Revista da Faculdade de Direito da UERJ, v.1, n. 19, jun./dez 2011.

direito de petição contra ilegalidade ou abuso de poder. É, sobretudo, no efetivo controle dos abusos de poder por parte dos agentes estatais que vai normativa do princípio da proporcionalidade.

Segundo Paulo Bonavides, a locução "proibição" ou "vedação do excesso" teve sua origem com juristas da escola alemã como Jellinek, Lerche, Klaus Stern, Kloepfer e Selmer, dentre muitos outros ${ }^{26}$. Muitas vezes tido como sinônimo do princípio da proporcionalidade, já que o integra, o princípio da proibição do excesso é tido pela jurisprudência alemã como de abrangência diversa do princípio maior ao qual está integrado. Foi Lerche que, ao separar os demais elementos ou subprincípios relativos à necessidade e a proporcionalidade em sentido estrito da adequação, acabou por conferir certa autonomia conceitual à vedação do excesso. Isto implicou em certa variação terminológica, pois, não obstante na teoria constitucional moderna os princípios da necessidade e da proporcionalidade serem estudados em separado, no tocante à definição do princípio da proibição do excesso, tanto um conceito quanto outro acima citado é integrados à delimitação do princípio.

No caso do abuso de autoridade, não se tem o risco de uma confusão de linguagem quanto à definição mais correta, visto que ao observar a ação estatal, no desempenho da função de seus agentes, como uma relação entre o fim da intervenção estatal e o meio empregado para que esta se torne efetiva, leva-se em conta a proibição quanto ao desequilíbrio do meio empregado, quanto aos fins colimados por essa respectiva intervenção.

Assim, as condutas dos agentes públicos na prestação de serviços de segurança, que envolvam o manejo de armas de fogo, vinculam-se inteiramente aos ditames do princípio exortado, uma vez que almeja mesmo o princípio a vinculação da conduta do agente público armado às diretrizes da racionalidade, quanto à quantificação do meio empregado no exercício da atividade policial, a fim de coibir excessos. Para o bom desempenho da função estatal, terão que ser levados em conta pelo agente público as prescrições jurídicas quanto aos direitos fundamentais sobremaneira resguardados pela Constituição. A regularidade, a legalidade e a legitimidade de seus atos só encontrarão ressonância jurídica conforme a obediência aos imperativos mediadores trazidos pelo princípio da proibição do excesso.

\footnotetext{
${ }^{26}$ BONAVIDES, Paulo. Direito Constitucional. São Paulo: Revista dos Tribunais, 2006. Pág.403-405.
} 
RFD- Revista da Faculdade de Direito da UERJ, v.1, n. 19, jun./dez 2011.

As práticas consideradas abusivas pelos agentes públicos deverão, portanto, ser

observadas à luz do disposto no artigo 5.o., parágrafo segundo da Constituição Federal. Isto implica em dizer que, não obstante os direitos fundamentais terem sido nominados no referido artigo 5.o., sua classificação não é exaustiva; pois outros direitos poderão decorrer da própria forma do Estado e do regime democrático por ele adotado. Não compete nem ao legislador e muito menos ao agente público, aplicador da Lei, obstruir o exercício de direitos, mesmo que não sejam aqueles expressamente declarados na Constituição, mas decorrem mesmo da natureza do regime. O que dizer da liberdade de expressão e de incolumidade física de que dispõem os cidadãos na ocorrência de manifestações pacíficas de rua, em não serem molestados pela iminência do ataque de cães ou de balas de grosso calibre? Ou ainda do direito que possuem os moradores de rua em locomover-se com suas caixas de papelão junto a barreiras policiais, mesmo não dispondo de cédula de identificação? Pode-se também falar do direito a que os encarcerados no sistema prisional têm quanto ao sigilo de sua correspondência ou quanto à privacidade na visita íntima de seus familiares ou patronos de causa, dentro desses estabelecimentos.

O princípio da proibição do excesso vem para estabelecer o equilíbrio entre a efetiva ação estatal, pautada pelos princípios da legalidade e da proporcionalidade, indo diretamente à questão do abuso de poder. Isto ocorre em função de que o fundamento do princípio da proporcionalidade encontra-se nos princípios da dignidade humana e da proibição do excesso, entre outros ${ }^{27}$. Torna-se bem empregada a manifestação do princípio quando se observa o exercício da jurisdição constitucional em matérias que levam a exortá-lo, quando, por exemplo, a jurisprudência do Supremo Tribunal Federal atende ao princípio no sentido de resguardar direitos fundamentais, dentre eles, o da incolumidade física do cidadão, com a proibição de uma desmedida e ilegítima violência estatal.

No tocante ao emprego da hermenêutica constitucional ao fato da aplicação do princípio aos casos de abuso de autoridade, deve-se entender a Constituição com o espaço onde se estabelecem as relações democráticas entre Estado e sociedade ${ }^{28}$. Desta forma, entendida a Constituição como uma zona de mediação entre legalidade e legitimação, estabelecendo o Estado Democrático de Direito, é nessa zona que devem ser encontrados os limites à atuação estatal, com a exata definição do alcance dos meios empregados pelo

\footnotetext{
${ }^{27}$ STRECK, Lenio Luiz. Jurisdição constitucional e hermenêutica. Rio de Janeiro: Forense, 2004.Pág.520.

${ }^{28}$ STRECK, Lenio Luiz. 2005. Ob.cit. Pág. 244.
} 
Estado na utilização de mecanismos com emprego do uso da força. É a Constituição que se constitui no ponto de partida hermenêutico para a compreensão de todo o ordenamento jurídico, mormente os institutos normativos de regulamentação e disciplina do emprego de armas pelos agentes estatais. Não basta uma obtusa exegese da Lei n.o. 10.826, que trata do desarmamento e da utilização de armas de fogo, para se definir a competência dos agentes públicos para a utilização de tais artefatos. O parâmetro constitucional vinculado ao exercício e respeito aos direitos fundamentais deve ser enxergado no sentido de assegurar a formação profissional que iniba os casos de violência irresponsável e desmedida, em casos de abuso.

Ora, até mesmo para se estabelecer uma nova política criminal de formação do aparelho policial, torna-se mister a observância do princípio, no justo aspecto da necessária profissionalização desse aparato. A violência policial vista como um defeito no profissionalismo e na gestão profissionais desses agentes estatais deve engendrar a luz do princípio estudado, a formação de um novo ethos na racionalidade administrativa, no sentido de estabelecer para o legislador novas diretrizes normativas quanto ao funcionamento das polícias. A possibilidade de emenda constitucional, a fim de adequar os dispositivos atinentes à organização do Estado e da administração pública, aos imperativos trazidos pelas garantias de direitos fundamentais, também é bem vinda, no momento em que se promove a estabelecer a correção de distorções.

Para se evitar que novos casos drásticos de inadequação do meio empregado ao fim destinado pelo agente público ocorram como no triste citado caso do ônibus 147 no Rio de Janeiro, é necessário que a autoridade pública tenha a devida consciência da mediação normativa estabelecida ao exercício da função policial, provocada pela invocação dos princípios constitucionais.

\section{CONCLUSÃO}

Conclui-se em breves linhas que o abuso de autoridade dos agentes estatais, especialmente daqueles habilitados legalmente ao uso de arma de fogo e dotados de legitimidade social para o exercício do cargo, pode ser evitado tomando-se conhecimento da violência policial em seu aspecto profissional. Além disso, é necessário firmar consciência a esses agentes de quais são seus direitos e deveres funcionais e de como os princípios 
RFD- Revista da Faculdade de Direito da UERJ, v.1, n. 19, jun./dez 2011.

constitucionais devem ser conhecidos e aplicados, a título de regular uma intervenção estatal que, não obstante esteja armada, pode produzir bem menos danos ao exercício da cidadania em um Estado Democrático de Direito, do que vem efetivamente ocorrendo no cotidiano da atividade policial.

Os princípios da legalidade e da proporcionalidade, entendido este último pelo subprincípio que o integra, que é o da proibição do excesso, por uma interpretação constitucional é justamente o princípio que funciona como viga-mestra para a regulação da atividade dos agentes estatais, no que versa o uso da força, e mais particularmente no que se destaca a intervenção policial, com emprego de armas de fogo. O monopólio estatal da força legítima, observado não apenas pelo prisma da legalidade, mas sim pela ótica do profissionalismo de seus agentes estatais, só poderá ter respaldo constitucional se os referidos agentes atentarem para o princípio norteador dessa atividade, que leva em conta não apenas o meio empregado, mas também às qualidades do agente a ser habilitado para tais funções, sua formação, e o necessário atendimento aos limites normativos concebidos pela própria ordem jurídica, dentro da concepção de um Estado Democrático de Direito. Somente desta forma dar-se-á a passagem de um Estado burguês eminentemente liberalnormativista, preso tão somente aos limites precários de regulamentos administrativos sob a égide um positivismo de cunho individualista, centrado na relação quem manda $\mathrm{X}$ quem obedece; para, ao contrário, ser dado um avanço significativo para a construção de um Estado de Direito eminentemente democrático e constitucional. É sob a lógica de um constitucionalismo dirigente e comprometido com a transformação social que poderá ser traçada a nova linha de uma ação estatal genuinamente cidadã e comprometida com o bem estar social, e não apenas com repressivas diretrizes estatais.

\section{REFERÊNCIAS}

BANDEIRA DE MELO, Celso Antônio. Curso de direito administrativo. São Paulo: Malheiros Editores, 2000.

BONAVIDES, Paulo. Direito Constitucional. São Paulo: Revista dos Tribunais, 2006.

FREITAS, Gilberto Passos. FREITAS, Vladimir de Passos. Abuso de autoridade. São Paulo: Revista dos Tribunais, 2001. 
DA MATTA, Roberto. Carnavais, malandros e heróis - para uma sociologia do ditema brasileiro. Rio de Janeiro: Rocco, 1997.

MESQUITA, Paulo, in Violência policial no Brasil: abordagens teóricas e práticas de controle. PANDOLFI, e outros (organizadores). Cidadania, justiça e violência. São Paulo: FGV, 1999.

SANCHES GARCIA, Maria Isabel. Ejercicio legítimo del cargo y uso de armas por la autoridad. Barcelona: Jose Maria Bosch Editor, 1995.

STRECK, Lenio Luiz. Hermenêutica jurídica em crise. Porto Alegre: Livraria do Advogado, 2005.

STRECK, Lenio Luiz. Jurisdição constitucional e hermenêutica. Rio de Janeiro: Forense, 2004.

TREVES, Renato. Sociologia do direito. Tradução Marcelo Branchini. Barueri: Manole, 2004.

WOLKMER, Antônio Carlos. História do direito no Brasil. Rio de Janeiro: Forense, 2002.

ZAFFARONI, Raul Eugenio. PIERANGELLI, José Henrique. Manual de Direito penal brasileiro-parte geral. São Paulo: Revista dos Tribunais, 2002. 